Diánoia, vol. 11, no. 11, 1965

\title{
SÓCRATES Y JESÚS
}

La primera y obvia aclaración que debemos hacer, después de haber estampado este título (que a algunos parecerá, y quizá con razón, audaz en demasía); es que el paralelo que el acoplamiento de ambos nombres pudiera sugerir, no lo es desde luego en el sentido geométrico del término: la equidistancia indefinida entre dos líneas que además, y según se dice, acabarían por reunirse en el infinito. No es así, estrictamente hablando, en ninguno de los consabidos paralelos entre personalidades históricas, y menos aún entre las dos que acabamos de nombrar, que no podrán converger del todo jamás, ni en el infinito.

No en sentido geométrico, sino más bien humano, el paralelo consiste simplemente en poner a una figura humana al lado de la otra, con objeto de iluminar juntamente semejanzas y diferencias. Tal ha sido el proceder desde las "Vidas Paralelas" por antonomasia, y por algo Plutarco remata el estudio de cada pareja con una "comparación" o "juicio de conjunto" ( $\sigma$ úyąı $\iota_{5}$ ), que no tendría razón de ser si de todo en todo fuesen semejantes una y otra vida y sus sujetos.

Pero aun reducida a estos términos la operación, no ha dejado de suscitarse la objeción de si estas aproximaciones o comparaciones, que no ofrecen mayor dificultad en individualidades mediocres, fácilmente reducibles a géneros o esquemas, son siquiera posibles cuando se aplican a los grandes hombres, en razón precisamente de que toda personalidad, mientras mayor es, y más compleja y profunda, es tanto más única, y más refractaria, por lo mismo, a toda comparación.

La objeción no tendría réplica si la comparación se hiciera con el designio anticipado de reducir una a la otra, o a un denominador común, a dos originalidades que posiblemente sean de todo irreductibles entre sí, pero no cuando la doble visión se realiza con mirada limpia y con ánimo exento de prejuicios. Con esta disposición, el cotejo puede ser precisamente una vía excelente para percibir las cualidades absolutamente privativas y originales de cada personalidad, contribuyendo así, por tanto, a su mejor conocimiento. Por algo nos dicen los lógicos que el conocimiento humano progresa por contraste, y que así conocemos, entre otras cosas, la luz por las tinieblas, no obstante ser cada uno de estos entes la negación total del otro.

Con las personalidades históricas no pasa así exactamente, pues a nadie se le ha ocurrido, que sepamos, comparar, por ejemplo, a Sócrates con $\mathrm{Na}$ poleón. Algo debe haber entre aquéllas de común, por lo menos según nuestro modo de entender, ya que la inteligencia humana no puede prescindir 
de los conceptos universales que aplica luego a tal o cual individuo, pero sin poder penetrar totalmente en el núcleo incomunicable de su individualidad. En toda biografía que no se limite simplemente a la narración de los hechos o actos de la percepción sensible (éstos sí, por definición, absolutamente incompartibles), tendrán que predicarse del personaje los consiguientes atributos laudatorios o vituperativos, que por ser inevitablemente términos y conceptos de virtudes y vicios, no podrán dejar de aplicarse igualmente a otros sujetos.

No nos extenderemos más en estos prenotandos sobre la posibilidad, los límites y el fruto que cabe esperar de estas comparaciones. En el caso actual, el hecho básico de haber sido Sócrates uno de los ejemplares más excelsos de la humanidad, llevó naturalmente a querer confrontarle con la otra figura en la cual, y por más que se contemple en ella puramente la humanidad misma, se encarna ésta en su más alto momento. Y si no en el mayor conocimiento de Jesús, a cuya imagen, según resulta de los cuatro evangelios, no hay nada que añadir, sí parece haber redundado esta aproximación en el más profundo conocimiento de Sócrates. No tenemos, por tanto, que preguntarnos más aquí sobre las condiciones de posibilidad de lo que ha sido, en fin de cuentas, una larga experiencia histórica, a la cual pasamos a referirnos en sus momentos más representativos, antes de dar, si podemos, nuestra opinión personal. ${ }^{1}$

\section{De los apologistas a la patristica}

Según Harnack, conocedor como pocos de la historia de la Iglesia primitiva, por más de un siglo, a partir de su fundación, no se registra una sola voz cristiana que pronuncie el elogio de Sócrates, mucho menos que se atreva a ponerlo en parangón con Cristo. $\mathrm{Y}$ no es que se desconociera al filósofo ateniense, ya que el cristianismo penetró muy pronto en aquel mundo mediterráneo: de Grecia al Asia Menor, tan saturado de cultura helénica, sino que, conforme a la hipótesis que creemos justa del propio Harnack, las diferencias fueron entonces del todo sobresalientes, como para obnubilar completamente las semejanzas. La apoteosis del conocimiento intuitivo sobre la fe; la autorredención por el conocimiento de sí mismo; la autonomía de la conciencia, que no consentía otra obedieñcia sino a la divinidad inmanente en la conciencia misma: todos estos, y otros análogos, que aparecían como los Leit-Motive del socratismo, parecían ser inconciliables con una moral y una religión no autónoma sino heterónoma, en cuanto del todo centrada y dependiente en absoluto de la persona de su divino Fundador.

1 Tomamos en esta parte como guía principal dos importantes estudios. El primero, el del gran teólogo protestante alemán Adolfo von Harnack, Sokrates und die alte Kirche, Discurso de Rectorado pronunciado en la Universidad de Berlín el 15 de octubre de 1900, Giessen, 1901. El segundo, el bello libro del P. Th. Deman, O. P., Socrate et Jésus, Paris, 1945. 
Desde la perspectiva histórica en que estamos, parece por lo demás bien natural esta actitud hermética, de clausura sobre sí misma, de la Iglesia primitiva. De haberse abierto luego a otras influencias, habría podido acabar en uno de tantos sincretismos como por entonces pululaban. Erale necesario ante todo, a la naciente comunidad, afirmarse sólidamente en su estructura dogmática y disciplinar antes de salir de sí misma para enriquecerse también con lo que le había sido ajeno. La mano tendida no es buena política sino cuando está ya uno seguro de sí mismo y en posesión de una personalidad invulnerable.

Todo esto debía ocurrir también con la Iglesia, y por ello no es sino hasta mediados del siglo II cuando puede efectuarse su gloriosa apertura a la filosofía griega, que en adelante iba ella misma a fecundar con su propio fermento, hasta producir al fin, por obra de la patrística, una filosofía cristiana. Es la empresa, como es harto sabido, de los llamados Apologistas griegos, a la cabeza de todos San Justino, verdadero fundador de la filosofía cristiana, y el primero igualmente que introduce la comparación entre Sócrates y Jesús. Es en el año 150 exactamente cuando verifica esta conexión, que desarrolla en las dos Apologías que envía a los emperadores Antonino Pío y Marco Aurelio, con quien la filosofía tuvo, por única vez en la historia, el cetro del mundo. Pongamos ante nosotros los textos que más nos interesan.

En la primera Apología, después de haber dicho que los hombres, engañados por el genio del mal, llamaron dioses a los demonios, añade San Justino:

"Sócrates, juzgando estas cosas a la luz de la razón y de la verdad, pretendió iluminar a los hombres y apartarlos del culto de los demonios; pero éstos, por intermedio de los malvados, lo hicieron condenar como impío, con el pretexto de que introducía nuevas verdades. Lo mismo hicieron después; porque no fue solamente entre los griegos, y por boca de Sócrates, como el Verbo ha hecho ofr la verdad, sino que los bárbaros fueron también ilustrados por el mismo Verbo, revestido de una forma sensible, hecho hombre y llamado Jesucristo..." 2

El otro texto de la segunda Apología dice así:

"Quienes vivieron antes de Cristo y buscaron, a la luz de la razón humana, conocer y dar razón de las cosas, fueron puestos en prisión como impíos e indiscretos. A Sócrates, que se aplicó a ello con más ardor que nadie, se le hicieron las mismas acusaciones que a nosotros. Decían de él que introducia divinidades nuevas y que no creía en los dioses admitidos en la ciudad. De su república arrojó a los malos demonios y a las divinidades que cometían los crímenes que cuentan los poetas, y expulsó también a Homero y a los demás poetas, apartando de ellos a los hombres y exhortándolos a conocer

$21^{a}$ Apol. V, 3-4. 
por la razón al Dios que ignoraban. No es fácil, decía Sócrates, encontrar al Padre y Creador del universo, ni tampoco, cuando se le ha encontrado, revelarlo a todos. Es lo que ha hecho Cristo por su propio poder. Nadie creyó en Sócrates, hasta que murió, por lo que enseñaba. Pero en Cristo, a quien Sócrates conoció en parte (puesto que era el Verbo que está en todo, que predijo el porvenir por los profetas y que tomó personalmente nuestra naturaleza para enseñarnos estas cosas), en Cristo creyeron no solamente los filón sofos y los letrados, sino los artesanos e ignorantes en general, y por él menosprecian la muerte; porque él es la virtud del Padre inefable y no una producción de la razón humana." 3

En el texto anterior es patente la inexactitud en que incurre Justino al atribuir a Sócrates pensamientos que no son sino de Platón (por encontrarse en diálogos que nadie tiene ya por históricamente socráticos), como la proscripción que de los poetas se hace en la República, y el maravilloso pasaje del Timeo, en el que Platón postula la existencia de un solo Hacedor y Padre del universo, en los siguientes términos:

"El cielo entero, o el mundo, o cualquier otro nombre más apropiado que pueda recibir... tha existido siempre, sin ningún principio generativo, o bien ha nacido y se ha originado de cierto principio? Ha nacido, porque visiblemente es tangible y tiene un cuerpo: y todo cuanto es sensible y que es aprehendido por la opinión y la sensación, está evidentemente sometido al devenir y al nacimiento. Ahora bien, y según afirmamos nosotros, todo cuanto ha nacido es forzoso que haya nacido por la acción de una causa determinada. Pero descubrir al hacedor y padre de este universo, es toda una hazaña, y al descubridor le es imposible divulgarlo a todos." 4

$\mathrm{Ni}$ siquiera es el Sócrates del diálogo quien pronuncia estas sublimes palabras, sino Timeo, el personaje central; pero no obstante este error, bien comprensible en una época carente aún de conciencia crítica, lo demás que se atribuye a Sócrates sí tiene base sólida en la letra misma de la acusación que motivó su proceso y su muerte. - Y lo que es absolutamente grande en estos textos de los apologistas griegos (por incorrecto que pueda ser el deslinde entre lo socrático y lo platónico) es la complexión, tan largamente fecunda en la historia, que ellos establecen entre la sabiduría helénica y la sabiduria judeo-cristiana, igualmente procedentes, una y otra, del Verbo o Logos del Padre, que es "la luz verdadera que ilumina a todo hombre que viene a este mundo".5 Por haber tomado literalmente, como debfa ser, la universalidad del texto joánico, fue posible tener igualmente por mensajeros de la Verdad subsistente a cuantos en alguna forma habian revelado la ver.

$32^{a}$ Apol. X, 4-8.

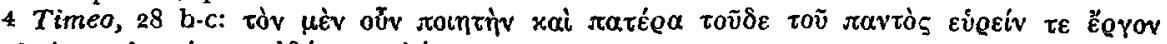

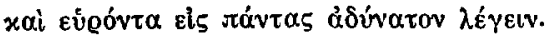

5 Ioan. I, 9 . 
dad a los hombres, ya fuesen los profetas de Israel o los filósofos de la Hélade. ¿No era el Timeo, en efecto, una réplica fiel del Génesis, con haber sido este documento absolutamente ignorado para el autor del primero? ¿No estaba en ambos, en oposición resuelta al politefsmo antiguo, el Dios único y creador del universo?

"Todos cuantos vivieron con el Logos fueron cristianos", dice en otro lugar San Justino; y a la cabeza de todos ellos está Sócrates, por cuya mediación se anunció el mismo Logos para oponerse a los falsos dioses. No obstante, Justino aclara debidamente, poniendo las cosas en su punto, que Sócrates no conoció a Cristo sino "en parte", y en su plenitud de encarnación, por el contrario, sólo los judíos, a quienes Justino continúa llamando, muy helénicamente por cierto, "bárbaros"; y que, por último, sólo por Cristo mueren los hombres, al paso que nadie ha muerto por dar testimonio de Sócrates y su doctrina.

Por la brecha abierta por San Justino, entran, para confirmar o ampliar el mismo paralelo, Taciano, Atenágoras, Apolonio y los grandes alejandrinos, como Clemente y Orígenes. El primero se complace en asociar textos socráticos y citas de la Biblia, e interpreta así mismo el demonio socrático como el espíritu del bien. Orígenes, por su parte, dice que aśl como Jesús abrió los brazos a los pecadores, Sócrates retiró a Fedón de una casa de lenocinio y lo condujo a la filosofía, e insiste en especial en la actitud de ambos ante la muerte. Tan familiar parece haber sido este aspecto de la comparación para aquellos cristianos, que muchos mártires se confortaron con el ejemplo no sólo de su Maestro, sino también con el de Sócrates, en el momento de morir. "Sócrates, en suma - concluye el padre Deman - goza en el cristianismo griego de los tres primeros siglos, de un favor casi universal." ${ }^{\circ}$

Este "casi" reposa apenas en una sola excepción -entre los apologistas griegos, una vez más- que es la del obispo Téofilo de Antioquía, quien no disimula su antipatía por el hombre que solía jurar por el can y por el plátano. El autor de las Homilias clementinas, por lo demás, no fue griego sino por la lengua, pues de raza era judeo-sirio. Pero la tendencia general, expresada clamorosamente por Clemente y Orígenes, fue la de tener a la filosofía griega, a partir de Sócrates, como precursora y heraldo de Cristo.

Pero si ésta era la actitud de los apologistas cristianos, era más que natural que sus enemigos, los adalides del viejo paganismo, se opusieran a ellos también en este punto del paralelo entre Jesús y Sócrates. Celso, Cecilio, Luciano, Libanio, Juliano, Marco Aurelio, entre otros, retuvieron la comparación, pero o bien para desvirtuarla, o ya, como era de esperarse, para utilizarla en exaltación de Sócrates y en desmedro de Jesús. Así, Celso dice que de Sócrates, más bien que de Jesús, tomaron los cristianos el mandamiento de no devolver mal por mal; lo cual, por supuesto, es bien difícil de probarse his-

6. Op. cit., p. 12. 
tóricamente. Galeno, por su parte, alaba a los cristianos porque, como Sócrates, desprecian la muerte; pero Marco Aurelio dice que lo hacen por espíritu de oposición, y no por juicio personal y sincero. ${ }^{7}$ Y el otro emperador filósofo, Juliano, tiene el siguiente elogio de Sócrates, de él tan sólo: "Sócrates es el único que, con muy pocos de sus émulos, pudo despojarse de la última de las túnicas del alma, que es el amor de la honra." 8

En actitud también antagónica a los apologistas griegos, aunque esta vez para humillar a Sócrates, estuvieron los apologistas latinos del cristianismo, menos comprensivos, como era natural, de la filosofía helénica. Novaciano, por ejemplo, llega a llamar a Sócrates el "bufón ático". Lactancio nos presenta un Sócrates nada atrayente, bien que reconozca que, con su doctrina del no saber, transformó la filosofía en ética. Y el campeón de la agresividad y el fanatismo (por algo hubo de salir de la Iglesia), es, por supuesto, Tertuliano, quien se complace en envilecer a Sócrates simplemente por su última recomendación del sacrificio del gallo a Esculapio, y ni siquiera reconoce el justo valor que tienen los maravillosos discursos que allí mismo, en el Fedón, se contienen sobre la inmortalidad del alma. No podía esperarse otra cosa de aquel mezquino espíritu para el cual no podía haber nada de común entre Atenas y Jerusalén, entre la Academia y la Iglesia. ${ }^{9}$

Hay que esperar al gran padre latinó, San Agustín, para presenciar la recepción triunfal de Sócrates en el Occidente cristiano. Copiaremos la página ilustre que sobre él escribió el autor de La Ciudad de Dios:

"Sócrates, pues, según la tradición, fue el primero que impulsó la filosofía en su conjunto a la reforma y disciplina de las costumbres, después de que todos sus precursores habian consagrado su mayor esfuerzo a investigar la física, es decir la naturaleza. ¿Lo habrá hecho así por el hastío que le producían materias oscuras e inciertas, aplicándose entonces a descubrir algo claro y seguro, como condición necesaria de la vida feliz, que es el único objeto de las vigilias y trabajos de los filósofos? ¿O no más bien, según una conjetura más benévola, habrá querido impedir que los espíritus manchados por las concupiscencias terrenales, intentaron elevarse a las cosas divinas? Es una cuestión que no me parece posible aclarar; pero en todo caso veía a estos hombres investigar las causas de las cosas, siendo así que, en su opinión, estas causas primeras y supremas residen únicamente en la voluntad de un solo y soberano Dios, y por esto no pensaba que pudieran ser percibidas sino con una inteligencia limpia. He ahí por qué juzgaba necesario purificar la vida por las buenas costumbres, a fin de que, estandio el alma libre del peso de las pasiones degradantes, pudiera elevarse por su vigor na-

7 Pensamientos, XI, \&.

8 Oratio III, 35 .

9 Quid ergo Athenis et Hierosolymis? Quid Academiae et Ecclesiae? Es éste, sin duda, el locus classicus de la incompresión y el fanatismo. 
tural a las verdades eternas y contemplar con una inteligencia pura la sustancia de la luz incorpórea e inmutable donde viven sin alteración las causas de todas las naturalezas creadas." 10

Como se ve, San Agustín no compara expresamente a Sócrates con Jesús, pero en cualquier revisión histórica de este paralelo, no puede dejar de figurar el encendido elogio que acabamos de leer, y según el cual, el eticismo de Sócrates habría sido la necesaria propedéutica para que el espíritu humano pudiera recobrar su vigor innato, y elevarse así a la contemplación de las cosas eternas, que son el objeto propio y la operación de la sabiduría. Bajo otro aspecto, San Agustín destaca, en innumerables pasajes de su vasta obra, el magisterio de Sócrates sobre Platón, cuya doctrina tuvo siempre el santo como la más próxima de la doctrina cristiana.

A la distancia en que nos encontramos, no es ya para nosotros una necesidad vital esta comparación que estamos hablando, como lo fue para aquellos hombres que habían conocido a Sócrates antes de llegar a Jesús. Pero como en la historia de la filosofía queda siempre algo más allá de la circunstancia temporal, lo caduco y lo vigente de aquella confrontación en la patrística, lo expresa muy bien Harnack en el siguiente pasaje:

"En cuanto a nosotros, no reivindicamos más a Cristo para la filosofía, ni a Sócrates para el cristianismo, pues sabemos que nada puede alcanzar la excelsitud del Evangelio. Pero con Justino, damos también testimonio de que en Sócrates ha obrado asimismo el Logos, y de que el siervo de la verdad es siervo de Dios." 11

No es diferente de esta apreciación del teólogo protestante la del filósofo católico Etienne Gilson, al comentạr este otro texto célebre de San Justino: "Todo cuanto en todos los demás ha sido bien dicho, nos pertenece a los cristianos." 12 "He aquí -comenta Gilson- formulada desde el siglo II en términos definitivos, la carta eterna del humanismo cristiano." 13

\section{La Edad Media y el socratismo cristiano}

Si la Edad Media, hablando en general, no se hace cuestión expresa del paralelo entre Jesús y Sócrates, es sin duda por el poco conocimiento que del Sócrates histórico se tiene en esta época; pero como en la susodicha comparación entran no solamente los personajes concretos, sino sus respectivas doctrinas, debemos considerar aquí lo que el mismo Gilson ha denominado el socratismo cristiano, ${ }^{14}$ y por más que desborde ampliamente la Edad Media, ya que tiene su origen en la patrística y su apogeo en Pascal.

10 De civ. Dei, 1. VIII, c. 3.

11 Op. cit., pág. 24.

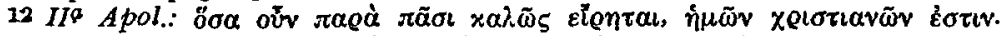

13 L'esprit de la p'hilosophie médiévale, Paris, 1944, pág. 24.

14 Gilson, op. cit., cap. xu: La connaissance de soi-mêmè et le socratisme chrétien. 
El punto de convergencia sería el "antifisicismo", o sea la primacía incondicional del estudio del hombre sobre el estudio de la naturaleza, postura común tanto a Sócrates como a los Padres de la Iglesia y sus continuadores. De Sócrates sabemos ya bien la experiencia que le llevó a adoptar esta definitiva actitud en su vida, ${ }^{15}$ y cumple apenas notar, como lo hace Gilson, que en él también, fue esta radical "conversión" motivada por un precepto religioso, ya que el oráculo de Delfos no era una cátedra de filosofía, ni siquiera cuando formulaba este mandato: "Conócete a ti mismo."

De fuentes mucho más ricas y explícitas disponían por su parte los pensadores cristianos para no abrigar duda alguna sobre el incomparable valor del hombre sobre la naturaleza, desde los textos del Génesis, en los cuales no puede estar más claro que el hombre no es tan sólo vestigio, como el resto de las criaturas, sino, además, imagen del Creador; la cual comentaba el sal. mista, en un texto tan caro a los medievales, al decir que: "En nosotros joh Señor! está sellado el resplandor de tu rostro." 16

Con mayor imperio aún, si cabe, que en estos textos, acabó de hacerse patente la dignidad humana con el dogma cristiano, que estaba apenas implícito en el Antiguo Testamento, de la resurrección de la carne, juntamente con la otra convicción de haberse pagado, por el rescate del hombre, de cada uno, el precio infinito de la sangre de Cristo. En adelante no es ya más el alma humana simplemente una idea o forma unida a la materia, y cuya su. pervivencia, por lo mismo, es problemática después de la destrucción del compuesto, sino una sustancia espiritual, inmortal y dotada de personalidad y destino único e incompartible. Nada hay que ni remotamente pueda com. petir con ella en valor; y el texto neotestamentario que quizá lo expresa mejor, es el que recoge las propias palabras de Cristo: "¿De qué aprovecha al hombre ganar todo el mundo, si es con daño de su alma?" 17

Este podría ser, pienso yo, el texto correspondiente, dentro del cristianismo, al de la inscripción délfica; y sea el que fuere, lo decisivo es la orientación igual hacia la interioridad humana, una de cuyas más refulgentes expresiones está en la conocida sentencia agustiniana: Noli foras ire. In te ipsum redi. In interiore homine habitat veritas.

No se trata, por supuesto, de una interiorización que lleve a un mero psicologismo, sino a un eticismo, a una purificación moral, como, según hemos visto, lo percibió tan bien San Agustín en el pensamiento socrático. En San Agustín, además, la introspección anímica desemboca nada menos que en Dios mismo, cuya presencia en el alma se le hace patente en aquellos correlatos intencionales: ideas o valores, que no pueden tener otro soporte

15 Cf. especialmente Xen. Memorabilia, $I V, 2,24-25$, y Platón, Fedón, 986 y sigs.

16 Signatum est super.nos lumen vultus tui, Domine... Ps. IV, 7 .

17 Matth. XVI, 26: Quid enim prodest homini, mundum si universum lucretur, animae vero suae detrimentum patiatur? 
que la Verdad subsistente. Esta dilatación de perspectiva, literalmente infinita, no la encontraremos en Sócrates, pero sí, una vez más, el moralismo

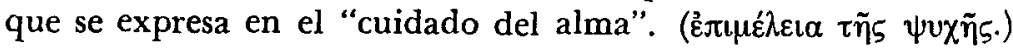

Más aún, y bien que, según dijimos, no sea éste el caso común, no faltan los escritores, y entre los mayores por cierto de la Edad Media, que de manera explícita incorporen a la filosofía cristiana el mandamiento délfico-socrático del "conócete a ti mismo". "Del cielo ha descendido este mandato", dice Ricardo de San Víctor en un célebre texto, en que cita literalmente la inscripción del santuario apolíneo: De coelo enim descendit, cum dixit:

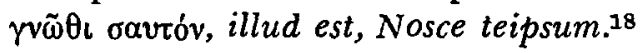

Por aquí se verá cómo los pensadores medievales comparten la idea formulada por los apologistas griegos, de que en los filósofos antiguos que de alguna manera conocieron la verdad, hubo una revelación natural del Verbo divino; y no sólo se siente así en la escuela agustiniana, ya que Santo Tomás hace suya reiteradas veces la fórmula de San Ambrosio, según la cual toda verdad, dígala quien la diga, proviene del Espiritu Santo: Omne verum, a quocumque dicatur, a Spiritu Sancto est.

Teniendo todo esto presente, cree Gilson que no hay ninguna intención pagana, antes todo lo contrario, en la famosa invocación de Erasmo: Sancte Socrates, ora pro nobis. "Si, en efecto, - se pregunta el filósofo francés- Sócrates fue cristiano a causa de su participación en el Verbo, y por esto, y a instigación del demonio, fue condenado a muerte ¿no es un mártir? $\mathrm{Y}$ si es un mártir ¿no es un santo?’"19

La cristianización de Sócrates, si podemos decirlo así, se mantiene, pues, de manera constante a través de la Edad Media y el Renacimiento, y en el siglo xvi (1652) aparece, sin sorpresa de nadie, el Socrate chrétien del escritor Guez de Balzac, libro que, por lo demás, no se ocupa para nada del personaje histórico. En opinión de Gilson,20 no es Balzac, sino Pascal, quien verdaderamente escribe el tratado del socratismo cristiano, que se contiene en sus muchos y admirables pensamientos sobre el conocimiento del hombre, como, por ejemplo, es el siguiente: "Es preciso conocerse a sí mismo, pues aunque esto no sirviera para encontrar la verdad, serviría por lo menos para ordenar su vida, y nada hay más justo." 21 Es ésta, probablemente, la más pura resonancia del imperativo délfico-socrático en la conciencia cristiana.

18 Benjamin minor, cap. 78.

19 Op. cit., pág. 24 n. El mismo autor agrega que es perfectamente tradicional y que responde al mismo espiritu la fórmula erasmiana: Christi esse puta quicquid usquam veri offenderis.

20 Op. cit., pág. 233.

21 Pensées, ed. Brunschvicg, n. 66. 


\section{El paralelo en la Ilustración}

En el siglo xvin aparece de nuevo, muy explícitamente, la comparación entre Sócrates y Jesús, y en primer lugar en la literatura alemana. Es sobre todo célebre una página de la Mesiada de Klopstock,22 en que el poeta finge el sueño que afligió a Porcia, la esposa de Pilato, ${ }^{23}$ de la manera siguiente.

A María, la madre de Jesús, que ha venido al pretorio a implorar la absolución de su hijo, le cuenta Porcia cómo se le ha aparecido Sócrates en su sueño de la víspera, para decirle que un Dios justo e indulgente preside en el otro mundo el destino de las almas, y que prosiguió luego, el mismo Sócrates, con estas palabras: "Los espíritus celestes celebran un santo misterio... Yo no puedo penetrar las tinieblas que lo envuelven, pero sí sé que en este momento está entre vosotros un justo que sufre lo que ningún mortal ha sufrido nunca. Por amor a los hombres, da él, que es más que un hombre, un ejemplo sublime de humildad ante Dios y de obediencia a su voluntad. „Desdichada de esta tierra si bebe la sangre del justo!"

Todo esto es ficción pura, por supuesto, al margen totalmente del texto evangélico; pero el hecho mismo de haberla urdido el poeta y de haber sido este episodio de la epopeya sagrada, según dice Harnack, altamente elogiado de los contemporáneos, demuestra cómo el problema de Sócrates y Jesús continuaba imponiéndose con toda su fuerza tantos siglos después de la actuación histórica del uno y del otro.

Hacia la misma época (la Mesiada es de 1769) los filósofos franceses de la Ilustración, particularmente Holbach y Voltaire, emprenden por su cuenta la comparación, pero esta vez, como era de esperar, para deprimir la figura de Jesús mediante la exaltación de Sócrates, a quien se presenta como el "santo del paganismo", y sus virtudes y su muerte como el paradigma insuperable del heroísmo moral. Contra esta tendencia reacciona el teólogo protestante Vernet, cuyo paralelo entre Sócrates y Jesús, por ser uno de los lugares clásicos en esta materia, vamos a transcribir íntegramente. Dice así:

"Si hubiera algún filósofo de la Antigüedad que pudiéramos osar compararlo con Jesús, en calidad de simple doctor, sería Sócrates. Ciertas personas, en efecto, se han complacido en destacar diversos rasgos de conformidad en la vida y el carácter del uno y del otro. Los dos hicieron descender, por decirlo así, la filosofía del cielo a la tierra, según se decía de Sócrates, al elogiarle por haber dejado la contemplación astronómica, a fin de enderezar todo el estudio de la sabiduría a las buenas costumbres y a la conducta de la vida civil. Uno y otro encontraron los espíritus estragados por sutilezas perversas. En Judea prevalecía la falsa devoción farisaica; en Atenas, la vana ciencia de los sofistas. Era menester arrancar la máscara a los unos y a los

22 Canto VII, versos 399 a 449 .

23 Matth. XXVII, 19. 
otros, para conducir a los hombres a lo verdadero y a lo simple; y esto fue a lo que cada uno de ellos se aplicó, por un método bastante semejante. Ni el uno ni el otro afectó un aire de singularidad; su vida fue del todo común, sociable y comunicativa. Les agradaba servirse de interrogaciones, comparaciones y parábolas, y entreverar sus discursos de máximas cortas y llenas de gracia. Ni el uno ni el otro dejaron nada por escrito, contentándose con formar discípulos que recogieron y publicaron sus enseñanzas. Uno y otro, el fin, al atraerse inocentemente el odio de los enemigos de la verdad, fueron públicamente acusados y condenados a muerte, y sufrieron su sentencia con grande resignación. Tales son las relaciones que se pueden notar entre los dos personajes; pero a ellas se podrían oponer diferencias muy grandes, y todas en ventaja del jefe de los cristianos, que tuvo concepciones más elevadas y costumbres mucho más puras, que enseñó una doctrina mucho más excelente, y que estuvo revestido de una autoridad infinitamente más respetable. Quienes no se cansan de elogiar a Sócrates, hasta ponerlo a la cabeza de todos los sabios de la Antigüedad ¿cómo podrían rehusar las mismas alabanzas a quien tanto le excede? $Y$ si al uno se le exalta a tal punto ¿cómo atreverse a degradar al otro, hasta tratarlo de visionario y extravagante? Dejo a otros juzgar si ha habido jamás parcialidad tan injusta." 24

En opinión de Masson, es "infinitamente probable" que de este pasaje de Vernet haya tomado Juan Jacobo Rousseau la idea de su propio paralelo, tan justamente célebre, y que en el texto principal donde se contiene, es como sigue:

" $i Q u e ́$ perjuicios o qué ceguera es menester para comparar al hijo de Sofronisco con el hijo de María! ¿Qué distancia del uno al otrol Sócrates muere sin dolor, sin ignominia, sosteniendo fácilmente hasta el fin su personaje, y si esta fácil muerte no hubiera coronado su vida, podría dudarse si Sócrates, con todo su espiritu, no habría sido otra cosa que un sofista. Dícese que inventó la moral; pero otros, antes que él, la habian puesto por obra, y Sócrates no hizo sino decir lo que ellos habían hecho, y poner en lección sus ejemplos. Arístides fue justo antes que Sócrates dijera lo que es la justicia; Leonidas había muerto por su país antes que Sócrates hubiera hecho un deber del amor a la patria; Esparta era sobria antes que Sócrates alabara la sobriedad, y antes que definiera él la virtud, abundaba Grecia en hombres virtuosos. Pero en cuanto a Jesús ¿de dónde pudo tomar, entre los suyos, esta moral elevada y pura, de la cual fue el único en dar las lecciones y el ejemplo? Del seno del más furioso fanatismo se hizo oír la más alta sabiduría, y la simplicidad de las más heroicas virtudes honró al más vil de todos los pueblos. La muerte de Sócrates, que filosofa tranquilamente con sus amigos, es la más dulce que pueda desearse; la de Jesús, que expira entre tormentos, injuriado, befado, maldito de todo un pueblo, es la más

24 Vernet, Traité de la vérité de la religion chrétienne, VI, 5. 
horrible de cuantas puedan temerse. Sócrates, al tomar la copa envenenada, bendice al que se la presenta y que llora; Jesús, en medio de un suplicio atroz, ora por sus verdugos encarnizados. En verdad que si la vida y la muerte de Sócrates son de un sabio, la vida y la muerte de Jesús son de un Dios." 25

Esta era la frase que ponía a Voltaire fuera de sí; pero si la examinamos bien, no hay en ella ninguna confesión de la divinidad de Cristo, sino que Rousesau se limita a ver en Jesús a un "hombre divino" - con aquella latitud predicativa de los antiguos-, un hombre nada más, en suma, y es ésta igualmente la opinión de autorizados intérpretes.

Dejando de lado este punto preciso de la divinidad de Jesús (que, por lo demás, no es de filosofía, sino de fe revelada), el paralelo de Juan Jacobo, admirable sobre todo en lo de la muerte de los dos personajes, es injustamente denigratorio de Sócrates en cuanto a negarle el título, que nadie más le ha disputado hasta ahora, de fundador de la filosofía moral. Contra esto sí debió haber protestado Voltaire o quien fuera, porque la cuestión no es que haya habido o no hombres virtuosos antes de Sócrates -esto no tiene la menor importancia - sino que nadie antes de él hizo de la virtud un objeto de reflexión filosófica, ni indagó, como Sócrates, el método por el cual podrian los hombres conocer y practicar la virtud. Esto es algo absolutamente firme en la tradición filosófica, cualquiera que sea el deslinde entre verdad y poesia en la personalidad de Sócrates, y Rousseau, por lo mismo, fue demasiado lejos en este punto.

Como introducción histórica, pensamos que es suficiente; y lo que encontramos de más significativo en los autores modernos, irá apareciendo en la síntesis que sobre esta base, y razonando además por nuestra cuenta, pasamos a hacer en seguida. Querríamos apenas observar que no tratamos aquí de penetrar en la insondable personalidad de Jesús, al modo que lo hacen los apologistas modernos, para los cuales el interés del paralelo con Sócrates es persuadir a los incrédulos de la irreductible y avasalladora originalidad de Jesús. No es éste, obviamente, nuestro actual propósito, sino que la única personalidad que nos interesa iluminar es la de Sócrates, y a esto nada más se endereza nuestra comparación.

\section{Misión de Sócrates y misión de Jesús}

Para nosotros, pues, el paralelo podría articularse en torno a los siguientes puntos de concordancia: la conciencia que de su misión tuvieron respectivamente Jesús y Sócrates; el celo de las almas, y las similitudes que pueden registrarse en la doctrina de ambos personajes, en su estilo de vida y en su muerte. Ponderémoslo todo en este orden.

Que Jesús se presentó siempre como ejecutor de una misión de lo alto,

25 Profession de foi du vicaire savoyard, ed. 1762, págs. 405-411. 
recibida directamente de su Padre, es algo que está en cada página de los evangelios, y sobre lo que, por lo mismo, no es preciso detenerse más. Ahora bien, y con la sola diferencia de no reclamar en su favor ninguna filiación o parentesco divino, sino como hombre nada más, Sócrates afirmó asimismo con la mayor energía, con absoluta claridad, sobre todo en su defensa ante sus jueces, que todo cuanto había hecho y la vida que había abrazado, no era, a sus ojos, sino el cumplimiento de una misión divina:

"En extrema pobreza me hallo — dicę- por el servicio de Dios"; ${ }^{26}$ por esta latria que consiste en examinarse a sí mismo y a los demás, y que ejercida sin intermisión, por toda la jornada y día por día, le ha impedido, como lo confiesa él mismo, hacer ninguna otra cosa de provecho para la república o sus familiares.

"En el puesto en que uno ha sido colocado por su jefe - sigue diciendoalli debe uno permanecer, a lo que me parece, cualquiera que sea el peligro, y sin tener en cuenta en absoluto ni la muerte ni otra cosa alguna, prefiriendo todo al deshonor." 27 Así lo hizo el propio Sócrates, y lo dice con legítimo orgullo, en el puesto que le asignó su general en Potidea, en Anfípolis, en Delio; y sería, por tanto, una extraña conducta de su parte el que por miedo de la pena que contra él piden sus acusadores, "hubiera yo de abandonar ahora el puesto en que me puso un dios, al ordenarme vivir para la filosofia", ${ }^{28}$ y ya sabemos que esta palabra no significa, en sus labios, una especulación teorética sobre los entes naturales.

De este llamamiento supremo no ha dudado jamás, por habérselo intimado la divinidad por todos los caminos posibles: "por los oráculos o en sueños, por todos los medios de que se ha servido siempre la voluntad divina al ordenar cualquier cosa a los hombres." 20 De esto está absolutamente cierto el que en lo demás profesa la nesciencia, como también de que es "cometer una acción injusta y baja el desobedecer uno a su superior, sea un dios o un hombre". 30

"¡Esto ya lo sé!", recalca con énfasis, y por esto declara que si sus jueces decidieran absolverlo con la condición de que abandonara el género de vida que hasta entonces ha llevado, tendría que responderles así: "Os lo agradezco, varones atenienses, y os amo, pero tendré que obedecer al dios antes que a vosotros; y mientras tenga un soplo de vida y sea capaz de obrar, no cesaré de aplicarme a la filosofía y de exhortar a cualquiera de vosotros con quien me encontrare." 31 "Obedecer a Dios antes que a los hombres", es por cierto, antes y despuéś que lo dijeran así Pedro y los apóstoles, uno de los

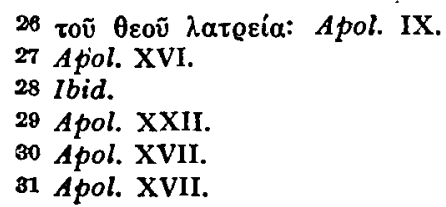


lemas del cristianismo. ${ }^{\mathfrak{2}} \mathrm{Y}$ lo es, porque no es sino la resonancia, en sus discípulos, del acatamiento incondicional de Jesús a la voluntad de su Padre, reiterado por vez postrera en el pavor indescriptible de Getsemaní.

Hasta donde le fue posible concretar su vocación divina quien, después de todo, no alcanzó a tener del monoteísmo una noción tan clara como un cristiano, de Apolo, del dios de Delfas, creyó Sócrates haber recibido la voz y el mandato. De cualquier modo, su misión fue bien conforme al espíritu apolíneo de predominio del principio racional, y en esto no se equivocó Nietzsche; pero con todo, su apelación a una entidad trascendente, a lo divino, está más allá del racionalismo. Bergson lo dijo muy bien: "Su misión (la de Sócrates) es de orden religioso y místico, en el sentido que damos hoy a estas palabras; su enseñanza, tan perfectamente racional, está suspendida de algo que parece sobrepasar a la pura razón." 33

A Bergson le interesa sobremanera ponderar este ápice, porque, según él, Sócrates habría encarnado mejor que nadie, en la antigüedad precristiana, la "emoción" original de que procede lo que el mismo filósofo denomina la moral "abierta", como lo habrían sido tanto la moral socrática como la moral cristiana en la comunidad primitiva. Por esto dice luego que el socratismo más puro, liberado de la dialéctica y la metatísica de la Academia, reaparece en el misticismo alejandrino; que por algo Plotino declaraba ser continuador de Sócrates, y que fue entonces cuando "por un tiempo, el mundo pudo preguntarse si iba a ser cristiano ó neoplatónico". "Era Sócrates quien se enfrentaba a Jesús",34 añade en seguida, contribuyendo así rexplícitamente al paralelo que estudiamos. Es posible que Bergson quiera llevar a Sócrates demasiado cerca de su propia filosofía, amenguando demasiado su intelectualismo, pero no puede desconocerse que, en efecto, hay una motivación supraintelectual en la vocación divina que creía él haber recibido.

Todo esto nos lleva naturalmente al otro tema (que podría muy bien no ser sino otro aspecto del anterior) del celo de las almas, por cuya salvación murió Jesús, ofreciendo al Padre el único rescate condigno de la culpa original. El sentimiento cristiano, además, ha intuido siempre como el correlato preciso de este celo, no la humanidad en general como un universal difuso, sino cada alma humana en particular. A cada una "busca" Jesús, como lo recuerda la liturgia en aquel hermoso verso del Dies irae, inspirado en el episodio de la samaritana:

\section{Quaerens me, sedisti lassus...}

"Cansado de buscarme, te sentaste." Así lo haría Sócrates también, en procura de las almas de sus conciudadanos, por las calles y plazas de Atenas.

32 Act. Apost. V 29: Oboedire oportet Deo magis quam hominibus.

33 Les deux sources de la morale et de la religion, Paris, 1932, pág. 60.

34 Deux sources, pág. 62. 
"En el principio de la misión socrática - dice el padre Deman- podemos descubrir una especie de fascinación ante la belleza del alma, exaltada por encima de todas las bellezas; la percepción aguda y entusiasta de esta realidad espiritual, la afirmación de su consistencia, en oposición a todos los inmoralismos, o más en general, a esta inmensa indiferencia de la mayoria por aquello que tienen de más precioso." 35

Entre los muchos textos que así lo corroboran, está la imprecación, igualmente perteneciente a su apología, que Sócrates dirige a su imaginario interlocutor, en los siguientes términos:

"¡Oh tú el mejor de los hombres! ¿Cómo es posible que siendo, como eres, ateniense, ciudadano de la mayor ciudad y de la más renombrada por su sabiduría y su poder, no te avergüences de no ocuparte sino de tu fortuna y de los medios de incrementarla lo más posible, así como de tu reputación y de tu honra, y que, en cambio, no pienses ni te preocupes de la sabiduría de la verdad ni de tu alma, procurando hacerla lo mejor posible?" 36

Bellas palabras, por cierto, en que la gloria y majestad de Atenas parecen estar en función de la excelencia propia de las almas, por su comercio con' la sabiduría.

El mismo motivo aparece en aquella encantadora escena del Protágoras, en la que Sócrates refrena el ardiente deseo de su amigo el joven Hipócrates, por ir cuanto antes a recibir las enseñanzas del célebre sofista. Pero ¿cómo va a "confiar su alma" Hipócrates a quien no conoce, pues no sabe siquiera lo que es un sofista ni qué conocimientos puede suministrar? "¿No comprendes a qué peligro expones tu alma?" Es un peligro incomparablemente mayor del que habria en comprar en el mercado un alimento adulterado, porque a éste hay tiempo de examinarlo en casa antes de ingerirlo, "en tanto que cuando se recibe una lección en el alma, se va uno de allí dañado o beneficiado". ${ }^{37}$

Tan sobresaliente debió haber sido en Sócrates este carácter, que sus mismos detractores lo reconocen espontáneamente; y así Aristófanes, aunque con intención maligna, lo llama un "psicagogo",38 o sea, según comenta Tovar, "conductor de almas, conquistador del espíritu, prácticamente un sacerdote de misterios o un guía de las conciencias". ${ }^{39}$

Como puede verse por todo lo anterior, en la actualidad parece imponerse, entre los exégetas o historiadores de la filosofía, la interpretación religiosa de Sócrates, contra la racionalista que procede de Nietzsche, y más lejanamente aún de Aristóteles, y más allá, si no precisamente en contra, de

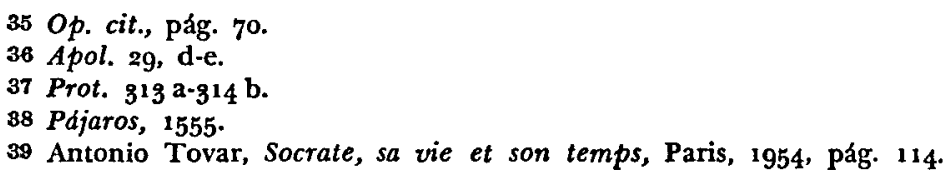


la interpretación puramente moralista o humanista de Heinrich Maier. De este modo, y sobre el dato firme del carácter de misión divina de que Sócrates se creía investido, Rodolfo Mondolfo no vacila en llamar "mística" aquella motivación, "con tal que -añade- no se entienda esta palabra en sentido irracionalista, pues sería contrario a la confianza incondicional que tenía Sócrates en el valor de la razón, sino como expresión de su honda conciencia de una misión sagrada, a la que se dedicó íntegramente y sacrificó su misma vida". 40 Y Jaeger, por su parte, al ponderar la autointerpretación de la misión socrática como servicio de Dios y cuidado del alma, dice con razón que estas expresiones "nos suenan a cristianismo".

\section{Moral socrática y moral cristiana}

Pasando al capítulo de la moral, es indudable, desde luego, que Sócrates no consumó una revolución de los valores tan total como la que proclamó Jesús en las Bienaventuranzas, o en el "mandamiento nuevo" del amor universal, con inclusión de los enemigos; pero sin llegar a tanta sublimidad, mucho se le asemeja la que el primero llevớ a cabo, no sobre el valor de la caridad, pero sí de la justicia.

Hasta Sócrates, en efecto, no era aún caduca, en la mentalidad helénica, la antigua "moral de señores" de la época heroica, y según la cual era la valentfa, o con mayor precisión, la fortaleza viril (andreia) la virtud suprema, encarnada en Aquiles como en su prototipo. No es sino en Platón y Aristóteles cuando la justicia asume definitivamente su función rectora y principal, y todo induce a creer que de este enaltecimiento fueron la enseñanza y el ejemplo de Sócrates la causa decisiva.

"El más sabio y el más justo" de todos los hombres conocidos por él, es el doble predicado que definitivamente adjudica Platón a su maestro, al terminar el relato de su muerte.41 Lo mismo casi dice el apóstol Pedro, de su maestro también, cuando increpa a los judios el haber renegado del "Santo y el Justo", para pedir, en cambio, el perdón de un homicida. ${ }^{42}$

En este punto preciso de la devoción absoluta a la justicia y al bien, que no tolera la menor excepción y por ningún motivo, el paralelo entre Jesús y Sócrates es, en verdad, impresionante. Al mandato contenido en el Sermón de la Montaña, de no devolver nunca el mal con el mal, ${ }^{43}$ con lo que se abroga allí mismo, explícitamente, la vieja ley del talión, corresponde puntuàlmente la doctrina socrática, reproducida en tantos diálogos platónicos, de que no es lícito jamás cometer injusticia, ni siquiera para res-

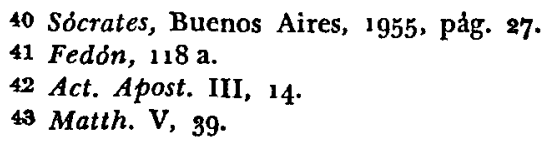


ponder a la injusticia recibida, lo cual aparecía no sólo como lícito, sino incluso como debido, en la moral de la época heroica. Asi lo pensaban aún los interlocutores de Sócrates en la República, para los cuales el "dar a cada uno lo suyo" de Simónides, debía forzosamente consistir en hacer el bien a los amigos y el mal a los enemigos. ${ }^{44}$ Pero Sócrates dice resueltamente que "éste no es el lenguaje de la verdad, pues para nosotros es cosa evidente que en ningún caso es justo hacer a nadie el mal". 45 Con esto concuerda el otro lugar tan conocido, de que es en todo caso preferible sufrir la injusticia a cometerla, ${ }^{46}$ al afirmar lo cual, Sócrates reconoce que está él solo contra la opinión de todo el mundo, con lo que está bien claro que se trata, aquí también, de una moral absolutamente nueva.

Tan nueva era, tan claramente derogatoria de la supremacía de los valores vitales, otra expresión, una vez más, de la moral heroica, que por algo resuenan en uno y otro diálogo, y precisamente al acabar Sócrates de sentar tales proposiciones, las terribles imprecaciones de Trasímaco y Calicles, que no son unos bárbaros, sino unos elocuentes representantes de la antigua moral. Para el primero, la justicia no puede estar disociada de la fuerza; para el segundo, la renuncia a la violencia para vindicar la injusticia, o sea la sumisión al proceso legal, es el pacto de los débiles, de los degradados, contra los fuertes. "Sufrir la injusticia -dice Calicles- no es propio de un hombre, sino de un esclavo." 47 La moral socrática es así, a los ojos del célebre sofista, literalmente una "moral de esclavos", o sea la misma denigrante calificación que Nietzsche habrá de imponer en la moral cristiana, con lo que se destaca, una vez más, el paralelo entre ambas. Por algo fue Nietzsche tan cordial enemigo tanto de Sócrates como de Jesús.

Que toda esta doctrina, a más de ser platónica, es genuinamente socrática, lo demuestra el hecho de haber sido no sólo profesada, sino vivida por Sócrates, y tan intensamente, que por ser fiel a aquella convicción, dio su propia vida, que es por cierto el mejor testimonio que un hombre puede dar de su doctrina. La razón decisiva, en efecto, que da Sócrates a Critón para declinar la fuga que éste le ofrece, es la de que con tal acto haria injusticia a la Ciudad, cuyas leyes aceptó voluntariamente por su larga vida y residencia en ella, y a cuyos decretos y sentencias, de cualquier género que fuesen juró, por este pacto implícito, incondicional obediencia. Ahora bien, Sócrates no niega que haya sido injusta la sentencia de muerte dictada contra él por sus jueces; sólo que esta injusticia no autoriza la que él cometería al eludir el cumplimiento del fallo, porque como lo dice una vez más, y sabiendo bien el efecto de estas palabras contra sí mismo: "No debe

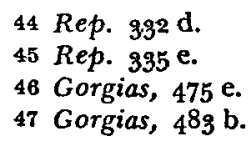


responderse a la injusticia con la injusticia, ni hacer a nadie el mal, aun a quien nos lo haya hecho." 48

Si esta doctrina tenía cabal aplicación en su caso, es, por supuesto, otra cuestión, y que nunca podrá dilucidarse, a lo que creemos, con absoluta claridad, ya que siempre podrá pretenderse que Sócrates habría podido desobedecer a la sentencia injusta de que él mismo era objeto, del mismo modo que una vez desobedeció a la que contra León de Salamina había dictado al poder entonces imperante. Desde el punto de vista de la legalidad formal y de la injusticia material, parece haber identidad entre los dos casos ¿por qué, entonces, Sócrates no observó en ambos la misma actitud de obediencia o desobediencia? La respuesta a esta pregunta quedó para siempre sepultada en la conciencia de Sócrates, y por esto es imposible decir más, pues no haríamos sino lucubraciones ociosas. Lo único decisivo es la doctrina misma, tan concordante, como lo estamos viendo, con la doctrina evangélica. Poder, gloria, riqueza y todo lo demás, todos los valores vitales, nada son y nada valen si han de comprarse con la injusticia, que es el mal del alma, de aquello cuyo valor es supremo.

Si la injusticia es el mal del alma, la justicia, a su vez, es su mayor bien y su verdadera dicha, y todo el resto es indiferente. "Para el hombre de bien -dice Sócrates al despedirse de sus jueces- no hay ningún mal ni vivo ni muerto, y los dioses no son indiferentes a su suerte." 49 Y Platón, prolongando por su cuenta el testamento de su maestro, escribe en la Repú- blica: "Sea que se encuentre en la pobreza, en la enfermedad o en cualquiera otro de estos estados que pasan por ser males, todo esto se convierte finalmente en un bien para el varón justo, ya sea en vida, ya después de su muerte. Los dioses, en efecto, no podrían desentenderse de quien se esfuerza en hacerse justo, y de llegar a ser, por el ejercicio de la virtud, tan semejante a la divinidad cuanto es posible al hombre." 50

Al contrario de las primeras palabras de este pasaje, las últimas, que introducen el nuevo tema de la imitación de Dios, no podrían ya, según el consenso común de los intérpretes, atribuirse al Sócrates histórico, ya no digamos en su tenor literal, pero ni siquiera en su contenido objetivo. Si la misión de Sócrates tiene una motivación religiosa, su moral, en cambio, no se inspira, hasta donde podemos juzgar, sino en la dignidad inmanente al hombre, en el valor del alma por sí misma; y no sería, por tanto, una moral religiosa, en cuanto que la religión supone la religación a un ente trascendente. En esto se distinguiría profundamente de la moral de Jesús, dependiente por entero de la filiación diviná, natural en Jesús mismo y adoptiva en el hombre, pero con una adopción tan íntima, por la gracia 
santificante, que el hombre llega a transformarse, según se atreve a decir San Pedro, en consors divinae naturae.51. De cualquier modo, y sea cual fuere la conceptuación posterior, la moral de la filiación y la imitación divina está bien clara en los evangelios, en pasajes como los siguientes: "Sed perfectos como vuestro Padre celestial es perfecto... A fin de que seáis hijos de vuestro Padre que está en los cielos." 62

Pero si todo esto está muy más allá de Sócrates, si está en su línea, en la prolongación de su pensamiento, como hemos dicho, la idea de la virtud como asimilación a Dios, que tan largamente desarrollan Platón y Aristóteles. Y así, al describir el Sócrates del Teetetes la. "evasión" de los males de este mundo, se expresa de este modo: "La , evasión consiste en asimilarse a Dios en la medida de lo posible; y esta asimilación se realiza haciéndose uno justo y santo en la claridad del espíritu... Porque Dios no es, bajo ningún aspecto ni de ninguna manera, injusto, antes bien es supremamente justo, y nada se le asemeja más que aquel de nosotros que llegue a ser el más justo." ${ }_{53} \mathrm{Y}$ en Aristóteles está la idea concomitante de la amistad con Dios, que se alcanza con sabiduría, en forma tal que el filósofo es "el más amado de Dios". ${ }^{54}$ Si no de Sócrates, sí son del socratismo estas maravillosas anticipaciones de la moral cristiana.

En su modo de vivir y de obrar, es algo que hiere la vista, por decirlo así, la semejanza entre Jesús y Sócrates. En su conducta personal, ante todo. Sin haber alcanzado la absoluta pureza del hijo de María (tan refulgente debió ser, que fue lo único en que no pusieron tacha sus enemigos), Sócrates se nos presenta como un raro ejemplar, en aquella época y en aquel medio, de observancia de la ley natural, en la monogamía por una parte, y en la abstención total, por la otra, del llamado pecado griego, según el irrecusable testimonio de Alcibíades.

Es el mismo Alcibiades quien habla también, en la famosa escena del Banquete,,$^{55}$ de las otras virtudes, todas en grado heroico, que sus contemporáneos admiraron en Sócrates: como soldado, su resistencia a la fatiga, su sangre fría y desprecio de la muerte; y en paz y guerra, su parquedad en el comer y en el beber. Nadie le vio jamás ebrio, y sin que, por otra parte, dejara de participar, como cualquier comensal, en los festines a que se le invitaba, al igual que Jesús de Nazaret, que comía y bebía con publicanos y pecadores, con gran escándalo de los fariseos. $\mathrm{X}$ así como Jesús se iba luego a orar en soledad, la potencia meditativa de Sócrates era tan extraordinaria, que una vez pudo estarse de pie, sin moverse de un lugar, por un día y una noche, concentrado en sus pensamientos.

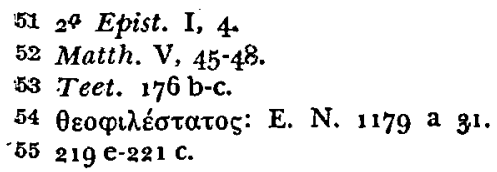


Sin dejar de tomar parte en el consorcio mundano, que era el medio necesario al cumplimiento de su misión, uno y otro estaban así más allá de este mundo, de todo cuanto está imbíbito en este término de mundo, según el insuperable texto joánico: concupiscencia de la carne, concupiscencia de los ojos y soberbia de la vida. ${ }^{50}$ Porque Sócrates también, si no precisamente exento de ellas como Jesús, supo vencer igualmente la segunda y la tercera, las concupiscencias espirituales, el apetito de riqueza y de poder. Del Hijo del Hombre, quien, según sus propias palabras, no tuvo ni dónde reclinar la cabeza, Sócrates se distingue apenas en tener un hogar, y en él un bien modesto pasar; pero en lo demás va también en pobreza suma ( $(\hat{v} v \pi \varepsilon v i \alpha \mu u \rho i \alpha)$, descalzo y astroso, predicando lo que, en el momento histórico que le tocó vivir, era también la buena nueva: si no precisamente el reino de Dios, sí el reino de la virtud y la justicia.

Ciertas particularidades de esta predicación o conversación, no dejan tampoco, por su similitud, de llamar poderosamente la atención. Es Aristóteles quien designa con el mismo nombre evangélico de "parábola" (comparación) el discurso socrătico, que, en efecto, al igual que el de Jesús, es un ascenso a las más altas realidades, partiendo de los datos más humildes y en un estilo familiar. Discurso que era, en un caso, escándalo para los fariseos, y en el otro para los sofistas, como el fastuoso Hipias, quien hace grandes aspavientos ante los ejemplos pedestres de que se sirve su interlocutor. Las parábolas evangélicas tienen, como es obvio, una poesía incomparablemente mayor que las de Sócrates, el cual confiesa, poco antes de morir, no haber tenido prácticamente trato con las musas; pero con esta diferencia, uno y otro discurso -más místico el de Jesús, más intelectual el de Sócrates-, tienden a mover directamente el corazón de los oyentes, y por esto mismo, es necesaria en ambos casos la comunicación oral.

Con esto tocamos el tema tan interesante, y tan imprescindible en este paralelo, del agrafismo en el magisterio de ambos personajes. Agrafismo y no agrafia, porque nadie va a suponer, ni en Jesús ni en Sócrates, una incapacidad de cualquier especie para expresar sus pensamientos por escrito. Una razón profunda, vivida si no planteada, debió existir para que no hubieran querido hacerlo así.

En lo que concierne a Jesús, lo mejor será dejar la palabra a Santo Tomás de Aquino, quien trata la cuestión muy de propósito, de la siguiente manera:

"Que Cristo no haya trasmitido su doctrina por escrito, se justifica ante todo por su dignidad. A la excelencia del maestro, en efecto, debe corresponder la excelencia del magisterio; por lo que Cristo, excelentísimo maestro, no pudo trasmitir su doctrina sino imprimiéndola en el corazón de sus oyentes... Y por esto también no quisieron escribir nada ni Pitágo-

56 I Epist. II, 16. 
ras ni Sócrates, que fueron, entre los gentiles, los maestros más excelentes... Por su alteza misma, además, la doctrina de Cristo no podía encerrarse en una expresión literaria, ya que en este caso habrían pensado los hombres que su doctrina no era más alta que su expresión escrita... La ley antigua, que se proponía en figuras sensibles, pudo por lo mismo escribirse en signos sensibles. Pero la doctrina de Cristo, que es ley del Espíritu de vida, debió escribirse, como dice el Apóstol (II Cor. III, 3) no con tinta, sino por el Espíritu de Dios vivo; no en tablas de piedra, sino en las tablas espirituales del corazón."57

Son palabras de una profundidad insondable, y que delatan luego el espíritu de la Iglesia católica, que contrariamente al protestantismo, ha puesto siempre la tradición oral en el mismo plano, cuando no en uno superior al de la letra escrita. Por esto ha podido decirse que aunque nunca hubieran sido escritos los evangelios, habría podido existir y perdurar una comunidad de hombres que fuese portadora del mensaje que los apóstoles y primeros discípulos oyeron del Maestro; porque, en fin de cuentas, Cristo no vino a escribir o dictar un libro, a imprimir unas frases en un papel o lo que fuera, sino en el alma misma de sus discípulos, siendo así esta impresión una transformación. Por esto también les dice San Pablo a los corintios, en el mismo pasaje citado por Santo Tomás, que la verdadera epístola (o sea el mensaje de Cristo) no es la que él está escribiendo, sino que la carta son ellos mismos, los cristianos de Corinto, impresión y expresión viva de una palabra igualmente viva, sin el toque letal que de algún modo tiene la palabra que ha sido consignada, para siempre inmóvil, en el texto escrito. Epistola nostra vos estis...

Buena parte de lo que dice Santo Tomás con referencia a Cristo, es también aplicable a Sócrates, como expresamente lo declara el santo. A quien, como Sócrates, no pretendía enseñar cosa alguna, según lo dijo continuamente, sino formar almas, le era indispensable -e insustituible - el diálogo viviente, a fin de encender en otros lo que a él le consumía, que era el amor de la verdad, y que de esta suerte, como dice Bergson, "se propagara el entusiasmo de alma en alma, indefinidamente, como un incendio".s8

En mi opinión muy personal, por último, hay en el agrafismo de Sócrates un motivo especial que no podría aplicarse al agrafismo de Jesús. Cuando, en efecto, hablamos del "magisterio" del uno y del otro, debemos siempre reparar en que no usamos aquel término, en uno y otro caso, con la misma propiedad. Jesús sí es, plena y absolutamente, el Maestro, porque es, con el mismo rigor, la Palabra del Padre; y aun aquellos que no han recibido esta revelación, entre los que le escuchan, se dan cuenta luego de 
que habla con autoridad propia: tanquam auctoritatem habens, y por esto no discute o investiga, solo o con sus interlocutores, sino que simplemente "enseña". Lo que Jesús "hizo y enseño", como dice San Lucas, es, ni más ni menos, lo que se contiene en los evangelios. $\mathrm{Y}$ Jesús mismo, en el último día de su vida mortal, dice ante el Procurador romano: "Yo por esto nací, y por esto vine al mundo, para dar testimonio de la verdad." 59 No de una verdad parcial, calificada o problemática, sino de la Verdad eternamente subsistente, que era él mismo.

Muy otro es el caso de Sócrates, y nadie más que él tuvo de ello perfecta conciencia. Al igual que Jesús, Sócrates también vino a este mundo para dar testimonio de la verdad, sólo que no de una verdad que ya poseyera, sino de una verdad por descubrir y conquistar. Siéndoles común el mismo amor de la verdad, hay entre ellos, bajo este respecto, toda la diferencia que los medievales establecían entre el viator y el comprehensor. $Y$ esto no apenas en razón de lo que sólo sería válido para un creyente, o sea la ciencia divina de Cristo, sino porque si algo hay cierto en la personalidad de Sócrates, es su doctrina del no saber, por lo que jamás pretendió ser profesor de sabiduría, ya no digamos mercader, como los sofistas. Lo que de éstos le distingue radicalmente, más aún que esta nota del desinterés moral, ,es que Sócrates, sin poseer tampoco la verdad, si cree en ella apasionadamente, es decir, en una instancia critica, superior e inmutable, de toda $y$ cualquiera proposición, y de aquí su indagación incesante - fruto de este amor a la verdad - de los conceptos universales. "Toda la originalidad de Sócrates -dice Windelband en el estudio que sobre él escribió- consiste en que él sí busca la verdad". ${ }^{60}$

Ahora bien -y es aquí donde interviene el agrafismo- si la verdad se produce y manifiesta en esa instancia crítica a la que los individuos conforman y sujetan sus opiniones particulares, el medio natural, o quizá el único, de esta epifanía de la verdad, parece ser la conversación en la comunidad filosófica, entre los amigos asociados en el amor de la sabiduría. Con referencia explícita el caso que estudiamos, dice el mismo Windelband:

"La verdad es pensamiento en común. Por esto no es la filosofía de Sócrates un inquirir o cavilar solitario, como tampoco una docencia y aprendizaje, sino una pesquisa en común y una apasionada conversación. Su forma necesaria es el diálogo." 61

Tan intensamente llegó a sentirse todo esto en la comunidad socrática, que el mayor de los socráticos, Platón, después de haber escrito maravillosamente durante toda su vida, acaba en su vejez, al escribir su célebre Carta VII (tendría entonces como 74 años), por externar sin reservas su desen-

\footnotetext{
59 Ioan. XVIII, 37.

60 Ub̈er Sokrates, en Präludien, Tübingen, 1915, vol. I, p. 67.

61 Ibid. ibid.
} 
canto del grafismo como medio idóneo de comunicación filosófica. "No es - dice- sino cuando se han frotado, penosamente, los unos contra los otros, nombres, definiciones, percepciones visuales e impresiones de los sentidos, cuando se ha discutido el tema en discusiones cordiales, en que la envidia no toma parte ni en el preguntar ni en el responder, cuando, en fin, sobre el objeto estudiado viene a resplandecer la sabiduría y la inteligencia con toda la intensidad que pueden soportar las fuerzas humanas." Como de la yesca y el pedernal (es la metáfora implícita en este pasaje), del frotamiento de las almas entre sí, y no de otro modo, se levanta la llama y la luz de la verdad.

Magisterio auténtico en Jesús, afán inquisitivo en Sócrates, pero el blanco, una vez más, es uno y el mismo: el unum necessarium, como lo dijo el Señor a Marta, lo cual es, en Jesús, el reino de Dios, y en Sócrates, a su vez -en su. reacción contra la polimatía de los sofistas- la purificación del espíritu y su apertura a un mundo de valores sustentados en el Espíritu infinito, que entrevemos a nuestro modo bajo la razón del bien. Platonismo puro esto último, se dirá, y no lo contradiremos, pero prolongación fiel de lo primero, como la línea del punto. Para consumar una misión semejante, fue preciso que Sócrates viviera como vivió Jesús, "en pobreza infinita, para servir a Dios". ${ }^{63}$

\section{Muerte de Sócrates y muerte de Jesús}

Ni Sócrates ni Jesús, por último, serían lo que son para la humanidad, hasta donde podemos juzgar, sino por su muerte. Pero en este punto precisamente, el más arduo tal vez del paralelo, me inclino a pensar que las diferencias son mayores que las semejanzas, según lo vio tan bien Rousseau en el pasaje que arriba extractamos. Con base en él, nos limitaremos a unas breves reflexiones, y lo demás hágalo cada cual con la lectura directa, que nada puede sustituir, del Fedón y del relato evangélico de la Pasión.

La semejanza más patente, y que, por lo demás, comparten con incontables figuras de la historia universal, es el haber sucumbido, uno y otro, voluntariamente, por dar testimonio de su misión, y por una sentencia injusta. Pero esto no es lo decisivo cuando se trata de lo más concretamente vivido, de lo más incompartible, como es la muerte, y la concreción material, por lo tanto, es a lo que primero debe atenderse, antes que a la proyección, en esa realidad singularísima, de conceptos universales.

Desde este punto de vista, pues, que creemos ser el justo, la muerte de Sócrates se nos ofrece en perfecta armonía con el espiritu del dios de Delfos que inspiró la misión del filósofo, o sea como un dechado insuperable

62 Carta VII, 344 b.

63 Apol. 23b. 
de serenidad y belleza. Con treinta votos apenas que decidieron el veredicto condenatorio, en un total de más de quinientos, la sentencia contra Sócrates no tuvo carácter ignominioso, y se ajustó, por lo demás, a las formalidades legales del procedimiento; todo muy en orden, a las formalidades legales del procedimiento; todo muy en orden, a despecho de la injusticia. Y en los días que siguieron hasta el retorno del barco de Delos, Sócrates no baja un punto de la "región azul de la serenidad". Con conceptos altísimos, en que hasta hoy se inspira la dialéctica entre seguridad y justicia, declina la proposición de fuga de Critón y espera tranquilamente el fin. Cuando éste llega, aleja a su mujer e hijos que le importunan con sus gimoteos; departe con toda paz con sus amigos sobre la inmortalidad del alma, y no hay en él sombra de congoja o cobardía, ni la menor alteración, hasta que apura el veneno. Es, de todo en todo, una muerte olimpica, la que más ha sobrepujado en la historia, probablemente, la condición humana.

Con Jesús es todo lo contrario. No son una mayoría de treinta los que le reprueban, sino todo su pueblo, que, enfurecidamente, reclama su suplicio, a cambio de la gracia de un asesino y malhechor. De los suyos, además (algo así como si Platón hubiera votado contra su maestro), de sus más intimos, le traiciona Judas, le reniega Pedro, le abandonan los demás, y apenas quedan, al pie de la cruz, su madre, Juan, y unas pocas mujeres fieles. El suplicio en que muere, además, es el más doloroso e infamante, el de los bandidos y los esclavos; y es llevado a él después de haber sido flagelado, escupido y befado hasta el mayor extremo posible por la soldadesca. Por último - y es algo en que debe repararse tanto o más que en lo anterior- Jesús, aunque obediente hasta el fin a la voluntad de su Padre, está tan lejos de la serenidad olimpica, que suda sangre en el huerto y pide que, si es posible, pase de él aquel cáliz; y luego, en la cruz, clama por el abandono en que Dios le ha dejado, hasta expirar, en fin, "con un gran grito". ${ }^{64}$

Cuando se medita en todo esto, se comprende que los estoicos encontraran esta muerte indigna de la paz augusta con que debe morir el Sabio. De aquí que, en la iconografía del Crucificado, me parezcan tan fuera de situación los Cristos dulces, limpios y sonrientes, o inclusive los extáticos (con la excepción tal vez del Cristo del Greco en el Louvre), y prefiera con mucho los que, o bien ocultan la faz atormentada, como los de Velázquez o Dalí, o que si la muestran, sea el rostro sanguinoso del luchador exhausto, como el Cristo de Grünewald, con la impronta del abandono, la ignominia y el pavor. La muerte de Sócrates, en cambio, sin ser precisamente una muerte académica, no está tan mal representada en el cuadro de David.

El por qué la diferencia entre una y otra muerte, hasta donde es po64 Matth. XXVII, 50. 
sible escrutar las razones del terrible decreto divino, estaría tal vez en que como Sócrates, después de todo, no vino a redimirnos, no tuvo por qué llevar a su último extremo, como Jesús, la encarnación de todo cuanto es el hombre y hay en él, lo excelso y lo afrentoso. En estos términos lo decia Claudel: Il faut pousser l'incarnation jusqu'au bout... Y antes de él lo había dicho Pascal asombrosamente: "Jesús está solo en la tierra, entregado solo a la cólera de Dios... Sufre esta pena y este abandono en el horror de la noche... Jesús estará en agonía hasta el fin del mundo." 65 Sócrates, en cambio, estuvo totalmente exento de agonía, porque no representaba propiamente la encarnación, sino la evasión triunfante del espíritu de una morada: el cuerpo, que hasta el fin del neoplatonismo, fue mirado como una cárcel. Por esto sentimos su muerte como un himno de liberación victoriosa, y la filosofía que él enseñó o que promovió, como una redención del espíritu, pero tan sólo de él. De ahí que lo que más nos conmueve en esta muerte, sea, como dice Windelband, la ausencia de toda emoción, de todo pathos en aquel incomparable sosiego y claridad; y en esto nada más radicaría, según el mismo filósofo, la diferencia entre el fin de Sócrates y el de tantos otros que, como el, han cruzado serenamente el umbral irreversible. ${ }^{66}$

No obstante, y una vez que han quedado así puntualizadas las diferencias entre uno y otro tránsito, quedaría en pie la concordancia fundamental que se desprende de estas bellas palabras, que nos servirán para concluir, de Adolfo von Harnack:

"Si se prescinde de su muerte, Sócrates podría haber pasado como un sofista en el noble sentido de la expresión... El elemento esencial en la vida de Sócrates es su muerte... En el mundo griego, en este luminoso mundo de goce y alegría sensual, introduce Sócrates la certeza y el fervor de una vida más alta, pero quien lo hace es el Sócrates moribundo y no el docente, o si se prefiere, el docente en la hora de su muerte... Que la vida terrestre no es el bien mayor, ni la muerte, persecución y torturas los mayores males, y que antes aún que a los olímpicos, hay que obedecer al Dios que habla en el interior, todo esto lo enseñó también Sócrates con su muerte." 67

ANTONio Gómez RoBledo

05 Pensées, Le mystère de Jesus.

66 Ich glaube, das Ergreifende darin ist der Mangel an allem Pathos... Da ist nur Ruhe und Klarheit... op. cit., pág. 86.

67 Sokrates und die alte Kirche, págs. 6-8. 